\title{
Gender Bias in Power Relationships: Evidence from Police Traffic Stops
}

\author{
Garrick Blalock, Jed DeVaro, Stephanie Leventhal, and Daniel H. Simon ${ }^{\dagger}$
}

First Version: December 31, 2006

This Version: February 22, 2007

We test for the existence of gender bias in power relationships. Specifically, we examine whether police officers are less likely to issue traffic tickets to men or to women during traffic stops. Whereas the conventional wisdom, which we document with surveys, is that women are less likely to receive tickets, our analysis shows otherwise. Examination of a pooled sample of traffic stops from five locations reveals no gender bias, but does show significant regional variation in the likelihood of citations. Analysis by location shows that women are more likely to receive citations in three of the five locations. Men are more likely to receive citations in the other two locations. To our knowledge, this study is the first to test for gender bias in traffic stops, and clearly refutes the conventional wisdom that police are more lenient towards women.

\footnotetext{
${ }^{\dagger}$ Blalock, Leventhal, and Simon are at the Department of Applied Economics and Management, Cornell University. DeVaro is at the School of Industrial and Labor Relations, Cornell University. We thank Nicola Persico at the University of Pennsylvania for graciously providing the data. We also thank Kate Antonovics at the University of California, San Diego, and Brian Withrow at Wichita State University for providing documentation for some of the data. Please direct correspondence to Garrick Blalock, 346 Warren Hall, Ithaca, NY 14853, +1 (607) 255-0307, garrick.blalock@cornell.edu.
} 


\section{INTRODUCTION}

For many decades the subject of differences between men and women in their treatment and labor market outcomes has been a core research topic in labor economics. A large fraction of this literature concerns gender differences in wages. A smaller fraction concerns gender differences in other labor market outcomes such as promotions. Questions about wages and promotions concern the extent to which worker productivity in the labor market is rewarded or compensated. In this paper we consider an alternative approach, to study punishments rather than rewards, and we do so in a non-workplace setting. That is, we consider the question of whether identifiable transgressive behaviors are more likely (or less likely) to be punished if the perpetrator is female rather than male. Specifically, we examine whether male drivers are more likely than female drivers to be ticketed when stopped by the police.

Although the distinction between rewards and punishments may be somewhat artificial, in the sense that any reward can be reinterpreted as the negative of a punishment, and vice versa, we believe that approaching the study of gender differences in treatments from the angle of punishments rather than rewards offers some noteworthy advantages. Further, for the purpose of understanding gender differences in punishments, studying the treatment of traffic violations is particularly revealing.

The notions of transgression and punishment in this context are simple and clearly defined. A transgression involves either a moving violation or a visible failure to maintain a vehicle, such as an expired inspection sticker or burned-out headlight. Punishment is defined as the receipt of a citation. A further advantage of the context is that the nature of the social interactions that precede and influence the decision about whether or not to punish is simple and clear, as well as constant across sample observations. Typically the incidents in question involve a focused interaction between only two parties (a single observer and a single perpetrator) for a relatively short period of time. ${ }^{1}$ In contrast, if we were to consider instead transgressions and punishments in the typical workplace setting, the nature and scope of transgressions would be quite diverse (e.g., arriving late for work, arguing with the boss, stealing from the company, using company phones for personal calls, shirking, or general poor performance), and the

\footnotetext{
${ }^{1}$ We have data on the duration of stops in two locations. In Wichita, Kansas, more than two thirds of all stops take 15 minutes or less, while in Bloomington, Illinois, more than three fourths of all stops take less than 15 minutes, with the median stop taking 10 minutes.
} 
punishments could range from mild rebukes to small or non-existent raises, denials of promotion, or firings. Furthermore, the nature of the social interactions that surround both transgressions and punishments is far more complex in the typical workplace, and incidents often involve multiple perpetrators and/or observers. All of these issues would complicate an analysis of gender differences in punishments.

A simple conceptual model is helpful for organizing one's thoughts about gender differences in the probability of punishment. Consider two individuals, called the perpetrator and the observer. The perpetrator is defined as an individual who might commit a transgressive action, and the observer is defined as an individual who can potentially observe a transgression and punish it. Let "Transgress", "Caught", and "Punish" denote the three events that the perpetrator commits a transgression, that the transgression is identified by the observer, and that the perpetrator is actually punished. Under the assumptions that the perpetrator is caught only when a transgression has been committed and that the perpetrator is punished only when a transgression has been committed and caught, we can decompose the probability that the perpetrator is punished into the product of three probabilities, as follows:

$$
\begin{aligned}
\operatorname{Prob}(\text { Punish })= & \text { Prob }(\text { Punish }, \text { Caught,Transgress }) \\
= & \text { Prob }(\text { Punish } \mid \text { Caught,Transgress }) \times \text { Prob }(\text { Caught } \mid \text { Transgress }) \times \\
& \text { Prob }(\text { Transgress })
\end{aligned}
$$

From this expression, it is clear that an observed gender difference in the probability of punishment could arise from a gender difference in any of the three probabilities in the product. That is, if women are more likely to be punished, this might be because women are more likely to commit a transgression, or because they are more likely to be caught after having committed a transgression, or because they are more likely than men to be punished after having committed a transgression and been caught, or because of any combination of these possibilities.

From the standpoint of thinking about whether punishment probabilities differ between women and men and whether such differences are due to gender discrimination, the three probabilities in the product are not all equally interesting. In particular, Prob(Transgress) is not of interest, since it concerns only the behavior of the perpetrator and not the interaction between the perpetrator and the observer, so it sheds no light on whether female perpetrators and male perpetrators are treated differently by observers. Furthermore, Prob(Caught | Transgress) will usually be of limited interest. While this probability is potentially affected by the behaviors of 
both the perpetrator and the observer, in many cases the perpetrator's gender is not known by the observer until after the perpetrator is caught, which limits the usefulness of this probability as an indicator of gender differences in treatment. Of greatest interest is Prob(Punish |

Caught,Transgress), and this probability is the focus of this paper, since the perpetrator's gender is virtually always known conditional on being caught, and whether or not punishment occurs frequently hinges on the nature of the interaction — typically occurring only after the perpetrator is caught $—$ between the perpetrator and the observer. Given that the perpetrator commits a transgression and is caught, is the probability of punishment related to whether the perpetrator is male or female? That is the fundamental question that concerns us.

Our particular context is that of traffic violations in five distinct regions of the United States: Bloomington, Illinois; Highland Park, Illinois; Wichita, Kansas; Boston, Massachusetts; and the entire state of Tennessee. In each incident involving a stopped vehicle, the perpetrator is the driver who committed a violation, and the observer is the police officer who stopped the driver. Conditional on having committed a violation and been stopped, a driver may or may not be punished by receiving a citation. Our main empirical research question is: Conditional on having been stopped, does the probability of getting a ticket depend on the driver's gender? ${ }^{2}$

According to conventional wisdom, the answer to this question is that men are more likely to be ticketed than women. To document the conventional wisdom, we conducted a poll of students in various classes at Cornell University and elsewhere. In each class, on a given day we distributed the following question, randomizing the order of the three responses to avoid issues of framing associated with the order and collecting the anonymous written responses before the students left the classroom: ${ }^{3}$

\footnotetext{
${ }^{2}$ We do not study Prob(Trangress); while it is quite possible that the probability of committing a violation differs between men and women, our focus in this paper is on potential gender differences in treatment. Similarly, we do not study Prob(Caught | Transgress), though it is quite possible that this probability also differs by gender. This might happen because of a gender difference in behavior (for instance, women might spend more time driving in school zones when school is in session, and police might tend to patrol in such areas and enforce the speed limit with particular zeal) or because in some cases the police officer might observe the driver's gender in advance, and this might influence the officer's decision to stop the driver, though in many cases the driver's gender may not be observed by the officer until after the decision to stop is made. This would surely be the case if the driver were stopped at night, an idea that was exploited in the analysis of racial profiling by Grogger and Ridgeway (2005), who refer to it as the "veil of darkness hypothesis."

${ }^{3}$ In the smaller classes, we know that every student in attendance on the survey day completed and returned a survey, though in the very large classes it is possible that some students exited the room without completing the survey.
} 
A driver is pulled over by police at a speed trap. The vehicle was traveling 12 miles over the speed limit. The officer is male and has the discretion to either issue a ticket or let the driver off with a warning. In this situation, would you say that:

a) a ticket is more likely to be issued if the driver is male?

b) a ticket is more likely to be issued if the driver is female?

c) male and female drivers are equally likely to be issued a ticket?

The overwhelming response was that males are more likely to be ticketed in this situation. Of the 539 students who answered the question, 458 (about 85.0 percent) said that males are more likely to be ticketed, while only 23 (about 4.3 percent) said that females are more likely to be ticketed, with 58 (about 10.7 percent) saying that males and females are equally likely to be ticketed. The pattern of responses within individual classes surveyed is similar, as revealed in Table 1.

In contrast to the conventional wisdom, our empirical results suggest that women are more likely to be ticketed than men in Bloomington, Wichita, and Tennessee, while men are more likely to be ticketed than women in Boston and Highland Park. To our knowledge, our study offers the first systematic evidence on whether and how the probability of receiving a citation, conditional on being stopped, differs by gender. Although we expect that our results will be of direct interest to some readers, our main motivation for the analysis is to shed light on the more general question of whether gender differences exist in the probability of punishment, and we see the context of traffic violations as offering a particularly useful setting for addressing this question empirically. While the context is narrow, we believe that our results may be informative in a variety of other social contexts (e.g., child rearing, student-teacher interactions, supervisorworker interactions, the behavior of judges and juries in a courtroom, etc.). Although gender discrimination potentially explains some of these results, alternative interpretations are also consistent with the data.

\section{THEORETICAL BACKGROUND AND RELATED LITERATURE}

Theories of gender discrimination based on personal tastes originated in economics with the work of Becker (1957) and have been extended in recent years to incorporate noncompetitive features of labor markets such as costly search. ${ }^{4}$ As discussed by Becker, in the typical workplace taste-based discrimination could take the form of employer discrimination, customer

\footnotetext{
${ }^{4}$ See Altonji and Blank (1999) for a survey of these and other economic models of discrimination.
} 
discrimination, or co-worker discrimination. In each case the members of one group (e.g., men) incur disutility from interacting with members of another group (e.g., women) and would therefore be willing to pay some amount to avoid such interactions. ${ }^{5}$ In the present context, tastebased gender discrimination would arise if police officers tended to be prejudiced in some way against drivers of the opposite sex. Since the vast majority of police officers are male, in practice this would usually mean that male officers were prejudiced against female drivers. ${ }^{6}$

While it might seem to follow that female police officers would be sympathetic towards female drivers, the "queen bee syndrome" defined by Staines, Tavris, and Jayaratne (1973) predicts the opposite. According to this theory, women who are individually successful in maledominated environments and attain positions of high status or authority are likely to endorse gender stereotypes. Such women view the women they supervise as competitors and have negative attitudes towards them, making them likely to discriminate against female subordinates. While the queen bee theory would seem to be more applicable in the context of supervisorsubordinate relationships, social role theory offers a reason why female officers may be biased favorably toward male drivers in our context. Social role theory argues that when job assignments depart from the social roles and hierarchies traditionally seen in the workplace, conflict can result that affects the behavior of both supervisor and subordinate (Eagly 1987). For example, if a male worker reports to a female supervisor, the female supervisor might behave deferentially towards her male subordinate to minimize the conflict and discomfort arising from a reporting structure that deviates from the social norm. In our context, female officers might feel less comfortable exercising their authority by issuing a ticket when the driver is male than when the driver is female. We cannot address any of these theories concerning the behavior of female officers empirically, because we do not observe the police officer's gender. However, these issues should not matter much given that the vast majority of police officers in the United States are male.

\footnotetext{
${ }^{5}$ The notion that people prefer to interact with similar others has been central to a large body of theoretical literature in social psychology (e.g., Byrne 1971, Tajfel and Turner 1986). This literature attempts to explain the preference for similarity by arguing that compatibility, interpersonal attraction, and identity reinforcement are all increased when people interact with others who are similar, whereas incompatibility, discord, and alienation result from interactions with others who are different. The idea that people prefer to interact with similar others has also been recognized in the sociological literature, in particular theories of organizational demography (Pfeffer 1983).

${ }^{6}$ Although we do not observe the gender of the police officers in our data, we know that in all five locations for which we have data at least 87 percent of the police officers were male. Furthermore, in 2003, 89 percent of police officers nationwide were male, according to the Uniform Crime Reporting Program Data on Police Employee.
} 
Standing in contrast to the taste-based theories of discrimination in which members of one group of individuals are prejudiced against members of another, the second major branch of the discrimination literature concerns theories of statistical discrimination, following the original papers by Phelps (1972) and Arrow (1973). These theories rely on an informational asymmetry that induces employers to rely on some observed personal characteristic (e.g., gender) as a signal of some unobserved characteristic of interest (e.g., worker productivity). That is, employers ascribe characteristics of a group to individual members of that group, in the absence of information on the characteristic of interest for the individual group members.

While the assumption that the productivity of potential hires is imperfectly observed by prospective employers seems eminently reasonable, in our context it is less clear what the fundamental information asymmetry would be that would give rise to statistical discrimination. The behavior of the driver that is most relevant to the situation at hand is rather easily observed by the police officer. Indeed, it is usually direct observation of this behavior that leads the driver to be stopped in the first place! We can think of only one plausible informational asymmetry that might be significant enough to warrant statistical discrimination. Suppose that male drivers are much more likely than female drivers to contest a traffic citation in court. If that is the case, police officers are likely to be aware of this fact and they might be more hesitant to cite male drivers, given the costs to the officer of having to appear in court.

A number of papers in the economics and organizational behavior literatures consider the relationship between managerial demographic characteristics and the characteristics of the workers hired (e.g., Giuliano, Levine, and Leonard 2006b, Carrington and Troske 1998, Wesolowski and Mossholder 1997, Tsui and O'Reilly 1989). The findings regarding gender in these studies are mixed. Evidence that the perceptions and behavior of authority figures are affected by the gender of subordinates has been documented in classroom settings, where gender discordance between students and teachers was found to affect teachers' evaluations of students (Dee 2005). Using panel data from a large American firm in the retail sector, Giuliano, Levine, and Leonard (2006a) found that gender discordances in supervisor-worker pairs have no statistically significant effects on rates of worker dismissals or promotions but have slightly adverse effects on worker quit rates. Their result for promotions parallels the results of Blau and DeVaro (2006); using a cross section of promotion decisions spanning many establishments in four metropolitan areas of the U.S., Blau and DeVaro found that gender differences between 
supervisors and their subordinates have no statistically significant effect on the gender gap in promotion rates for subordinates.

While we do not know of other studies of gender differences in treatment conditional on a traffic stop, ${ }^{7}$ following the work of Knowles, Persico, and Todd (2001) a recent literature has emerged concerning racial profiling and vehicle searches in traffic stops. ${ }^{8}$ The theoretical model proposed in Knowles, Persico, and Todd (2001) implies that the guilt rate, the proportion of vehicle searches that reveal illegal drugs, should not vary across groups if police are unprejudiced. Using data from Interstate 95 in Maryland, the authors find equal guilt rates for blacks and whites and conclude that the data are not consistent with racial prejudice against blacks. ${ }^{9}$ Hernandez-Murillo and Knowles (2004) develop a model of police search decisions that allows for nondiscretionary searches and derives tests for racial bias in data that mix different search types. The empirical tests reject unbiased policing as an explanation of the disparate impact of motor-vehicle searches on minorities in Missouri. Anwar and Fang (2006) propose a theoretical framework that allows officers to use information they gather about drivers during a stop in deciding whether to conduct a vehicle search. ${ }^{10}$ They then use data from the Florida State Highway Patrol on all vehicle stops and searches conducted on Florida highways between January 2000 and November 2001 for empirical tests, rejecting the hypothesis that troopers of different races are monolithic in their search behavior, but failing to reject the hypothesis that

\footnotetext{
${ }^{7}$ Although we could find no studies using traffic stop data to compare ticketing rates for men and women, two Department of Justice reports $(2001,2005)$ compiled from drivers' self-reporting indicate that women receive a citatation 3 percent less often than men conditional on being stopped by police.

${ }^{8}$ Though it does not focus on traffic stops, the related analysis of Donohue and Levitt (2001) uses panel data for 122 large U.S. cities to examine the relationship between the racial composition of a city's police force and the racial patterns of arrests. Increases in the number of minority police are associated with significant increases in arrests of whites but have little impact on arrests of nonwhites. Similarly, more white police increase the number of arrests of nonwhites but do not systematically affect the number of white arrests.

${ }^{9}$ Three recent papers extend the theoretical analysis of Knowles, Persico, and Todd (2001) and conduct additional empirical tests. Persico and Todd (2004) show that the test proposed in Knowles, Persico and Todd (2001) can also be applied in a more general environment where police officers are heterogeneous in their tastes for discrimination and in their costs of search and motorists are heterogeneous in their benefits and costs from criminal behavior. Applying their proposed tests to data on police searches of motor vehicles gathered by the Wichita Police Department, they find evidence consistent with the notion that police choose their search strategies to maximize successful searches and not out of racial bias. Antonovics and Knight (2004) use data from the Boston Police Department to show that, consistent with preference-based discrimination, officers are more likely to conduct a search if the officer and driver are of different races. Dharmapala and Ross (2004) re-examine the data used in Knowles, Persico, and Todd (2001), showing that the data are consistent with prejudice against black males, no prejudice, and reverse discrimination, depending on the type of equilibrium that exists.

${ }^{10}$ The model assumes that officers observe a characteristic, $\theta$, which is correlated with the likelihood that the driver is guilty but is unknown to the driver when he decides to carry drugs or other contraband. The same assumption appears in the model of Bjerk (2005).
} 
troopers of different races do not exhibit racial prejudice. Finally, Grogger and Ridgeway (2005) propose methods to test for racial profiling that rely on the hypothesis that after dark police are less likely than during daylight to know the race of a driver before making a stop. They apply their methods to data from Oakland, California, finding little evidence of racial profiling in traffic stops.

\section{DATA AND EMPIRICAL ANALSIS}

To assess whether driver gender influences the likelihood of receiving a ticket, we use data on traffic stops from five locations: Bloomington, IL; Boston, MA; Highland Park, IL; Tennessee; and Wichita, KS. ${ }^{11}$ Each dataset offers information on the reason for the traffic stop (Table 2), whether or not a ticket was issued, driver gender, and a variety of other driver, vehicle, and contextual factors.

Table 3 reports some descriptive statistics for the variables that we use in our estimation. While we do not observe the gender of police officer by traffic stop, we do include the percentage of male police officers in each location. In all five locations, the overwhelming majority of police officers are male, with Boston having the smallest fraction of male officers ( 87 percent). It is interesting to note that there is substantial variation across the five datasets on a variety of dimensions. In particular, in Boston and Highland Park just a little more than half of all traffic stops result in a ticket being issued, while in Tennessee and Wichita more than 75 percent of all stops result in a ticket.

To test the conventional wisdom that female drivers are less likely to receive a ticket, conditional on being stopped, we initially estimate a series of baseline probit models that include driver gender as the only right-hand-side variable ${ }^{12}$. We then introduce other controls to see whether these variables influence the results. In all cases, we report marginal effects, i.e., the difference between the predicted probabilities of receiving a ticket when the driver is female versus when the driver is male, evaluating all other covariates at their sample means. In each case, we also report the probability of a male receiving a ticket. This allows us to assess the magnitude of the marginal effect for female drivers as a percentage increase in the likelihood of a female driver receiving a ticket relative to the probability of a male driver receiving a ticket.

\footnotetext{
${ }^{11}$ We downloaded these datasets from the website of Nicola Persico at the University of Pennsylvania.

12 This is equivalent to simply considering the difference in the probability of receiving a ticket for men and women. We estimate probits for consistency with later analyses in which we include control variables.
} 
For example, consider Table 4, which examines the impact of a driver's gender on the likelihood of receiving a ticket, conditional on being stopped. For this initial analysis, we pool traffic stops from all five locations and include location fixed effects. The results reveal that women are a statistically insignificant 0.3 percentage points less likely than men to receive a ticket. In other words, while men receive a ticket in 60.1 percent of all traffic stops, women receive a ticket in 58.8 percent of all stops, or 0.3 percentage points less often. Since the marginal effect for female drivers is small and statistically insignificant, one might be tempted to consider ticket issuance to be gender-neutral. However, the location fixed effects are highly significant. Therefore, we disaggregate our analysis by location in Table 5 .

In Table 5, we examine the impact of the driver's gender on the likelihood of receiving a ticket, conditional on being stopped, by location. Doing so reveals substantial variation across the five locations. In Panel A, as in Table 5, we pool all types of traffic stops. Here, we see that in Bloomington, women are 3.2 percentage points more likely to be ticketed than men, in Tennessee women are 1.5 percentage points more likely to be ticketed, and in Wichita women are 3.8 percentage points more likely to be ticketed. In Boston and Highland Park, men are more likely to be ticketed. These results indicate that in Bloomington, for example, where male drivers are ticketed in about 68 percent of all traffic stops, female drivers are about 4.7 percent more likely to get a ticket, while in Tennessee, female drivers are only about 1.9 percent more likely to get a ticket. ${ }^{13}$

We next look at traffic stops that involve a moving violation, such as speeding, failing to stop at a traffic light, and a variety of other offenses. The results in Panel B of Table 5 are quite similar to those in Panel A, with women being more likely to receive a ticket in Bloomington, Wichita, and Tennessee, and less likely to receive a ticket in Boston and Highland Park. The similarity between the results for all violations and those for moving violations is not surprising given that in all five locations over 60 percent of traffic stops involve moving violations.

When we restrict our attention to non-moving violations, including defective equipment, missing or expired paperwork, and seatbelt/child safety restraint violations (see Table 2), we see very different results. The results in Panel C of Table 5 show that in Boston, women are 5.7

\footnotetext{
${ }^{13}$ To calculate this figure we divide the marginal effect by the corresponding probability that a male driver receives a ticket.
} 
percentage points (about 10.5 percent) more likely to receive a ticket, while in the other four locations we find no statistically significant difference between men and women.

Our results thus far suggest that ticketing rates by gender vary substantially across locations and by type of violation, but they do not appear to conform to the conventional wisdom that women are less likely than men to receive tickets when stopped. However, since our survey pertained to speeding tickets, we now turn our attention to traffic stops where the driver was speeding, using the three datasets (Bloomington, Highland Park, Boston) that include the driver's speed. We control for the degree of speeding (as we also did in our survey question), by including "miles per hour over the speed limit" in our probit models. Furthermore, to allow for diminishing marginal effects of excess speed we include a squared term as well.

The results for speeding violations, which we report in Panel D of Table 5, reveal that in Bloomington, women are 3.7 percentage points (about 4.4 percent) more likely than men to receive a ticket, in Boston they are 5.4 percentage points (about 10 percent) less likely to receive a ticket, and in Highland Park men and women are equally likely to receive a ticket. Once again, these results show substantial variation across locations but little support for the conventional wisdom.

Omitted factors that influence ticketing rates and that are correlated with driver gender could potentially explain why the results in Tables 5 and 6 do not support the conventional wisdom. For example, it may be that women and men drive different kinds of vehicles and that the vehicles women tend to drive increase the likelihood of being ticketed. To consider this possibility, Panel A of Table 6 includes indicator variables for vehicle model, year, and primary color, using the two datasets that include information on vehicle type. In Bloomington, we find that including these controls reduces the positive effect of being female by about half, from 3.2 percentage points to 1.7 percentage points ( 2.5 percent). In Boston, the inclusion of vehicle controls increases the magnitude of the negative effect of being female by about half, from -1.7 percentage points to -2.5 percentage points ( -4.5 percent).

In Panel B of Table 6 we control for two other driver characteristics, age and race, which might influence ticketing. All of the datasets have information on driver race, while all but Highland Park have information on driver age. We include dummy variables for three race categories: black, Hispanic, and other (in all three cases, white drivers are the omitted category). Similarly, we include dummies for age categories. In all cases, the inclusion of age and race 
dummies has little impact on the results, though we do see some evidence that younger drivers are more likely to be ticketed, particularly in Bloomington and Boston. Moreover, in four of the five locations, we find that black drivers are less likely to be ticketed, while Hispanics are less likely to be ticketed in Tennessee. ${ }^{14}$

Although it does not appear that other driver or vehicle characteristics are responsible for our results, one might still believe that these, or other, factors influence gender ticketing rates. For example, proponents of the conventional wisdom might suspect that male police officers are more likely to be lenient with younger female drivers who they may consider attractive. To consider this possibility, we analyze younger and older drivers separately. ${ }^{15}$ When we consider all traffic stops, the results in the first two columns of Panel A in Table 7 show that in Bloomington older female drivers are ticketed about 5.4 percentage points ( 8.2 percent) more frequently than older male drivers, while young female drivers are ticketed about 1.9 percentage points (2.7 percent) more frequently than young male drivers. We find a similar pattern of results in Wichita, although the difference between older and younger drivers is not statistically significant. In Boston, where women are less likely to be ticketed than men, we find a slightly bigger difference among younger drivers. However, this result is also not statistically significant. Surprisingly, in Tennessee we find that while older women are ticketed at the same rate as older men, younger women are more likely than younger men to receive a ticket, with this difference approaching significance at conventional levels $(\mathrm{t}$-stat $=1.53)$.

To further examine differences between younger and older women, we again separately consider different types of tickets. The results for moving violations, displayed in Panel B of Table 7, are similar to those for all violations. In Bloomington, older female drivers are ticketed nearly eight percentage points (11.2 percent) more frequently than older male drivers, while young female drivers are ticketed three percentage points ( 4 percent) more frequently than young male drivers. In Boston, older female drivers are 3.3 percentage points ( 6.3 percent) less likely to be ticketed than older male drivers, but younger female drivers are five percentage points $(8.4$ percent) less likely to be ticketed than younger male drivers. In Tennessee, being female

\footnotetext{
${ }^{14}$ We also tried controlling for the number of passengers in the vehicle, whether the driver was a resident of the state in which he/she was stopped, as well as the year, month, and day of the week that the stop occurred. Doing so does not change our results.

${ }^{15}$ Of course, the results we report are identical to those obtained by estimating the model for all traffic stops and interacting a dummy for young drivers with the female dummy.
} 
increases the likelihood of being ticketed more among younger drivers than among older drivers, although the difference between the two age groups is no longer statistically significant.

The results for non-moving violations, displayed in Panel $\mathrm{C}$ of Table 7, are a bit different. In Bloomington and Wichita, being a woman reduces the likelihood of being ticketed more for younger women than for older women, although this difference is not statistically significant in Bloomington. In Boston, we find the opposite result, as the effect of being female increases the likelihood of being ticketed more for younger women, but this difference is not significant. In Tennessee, the effect of being a woman slightly increases the likelihood of being ticketed for younger women but reduces it for older women. This difference is nearly significant at conventional levels ( $\mathrm{t}$-stat $=1.57)$.

Taken together, the results in Table 7 provide a bit more support for the conventional wisdom, since in several cases the female driver effect is less positive or more negative for younger women. Nonetheless, in most of these cases, the effect of the female dummy remains positive, even for younger women, indicating that younger women are more likely to be ticketed than younger men. Thus, our overall conclusion remains that there is little support for the conventional wisdom that female drivers are less likely than male drivers to be ticketed at a traffic stop, even among younger drivers.

Another factor that might influence our results is the time of day when the traffic stop occurs. If the probability of receiving a ticket, conditional on being stopped, is higher during the day than at night, and if women drive more during the day, then this could explain why we find that women face higher ticketing rates than men.

To consider this possibility, we first compare the results for all violations at night (8pm6am) versus during the day (Panel A of Table 8). In Bloomington, we find that at night our earlier result reverses, with women being 6.5 percentage points (11.9 percent) less likely than men to be ticketed at night, while in Boston our results indicate that women are also less likely to get a ticket at night ( $\mathrm{t}$-stat=1.61). However, the difference in ticketing rates for men and women is smaller at night than it is during the day (although the difference is not statistically significant). In Wichita, the difference in ticketing rates between men and women is eliminated at night.

In Panel B of Table 8 we report results from these models when restricting the sample to traffic stops involving moving violations. The results in Bloomington are again opposite for 
night and day. During the day women are 3.3 percentage points (4.1 percent) more likely than men to receive a ticket for a moving violation, while at night they are 7.7 percentage points (14.7 percent) less likely than men to receive a ticket. In Boston, the results are fairly similar for daytime and nighttime stops; in both cases, women are about four percentage points less likely than men to receive a ticket for a moving violation. In Wichita, the results for moving violations also reverse at night. Women are 1.5 percentage points ( 1.7 percent) more likely than men to receive a ticket for a moving violation during the day, while at night they are 2.3 percentage points (2.8 percent) less likely to receive a ticket.

Finally, in Panel $\mathrm{C}$ of Table 8 we report results when restricting the sample to traffic stops involving non-moving violations. In Bloomington, female drivers are almost six percentage points (9.8 percent) less likely than male drivers to receive a ticket for a non-moving violation at night, while during the day there is no difference. In Wichita, women are 4.1 percentage points (5 percent) more likely to receive a ticket for a non-moving violation during the day, while at night they are 3.2 percentage points (4.1 percent) less likely to receive a ticket. In Boston, we see that during the day women are 5.8 percentage points (10.5 percent) more likely to receive a ticket for a non-moving violation, while they are 3.9 percentage points ( 7.6 percent) more likely to receive a ticket at night.

Taken together, these results indicate that while women are more likely to be ticketed during the day, at night women are less likely than men to receive a ticket. There are two possible explanations for these divergent results. The first is that driver gender influences the probability of being stopped. During the day, if police can determine driver gender before stopping a vehicle, then police may be more likely to stop male drivers. In other words, police may use gender profiling in traffic stops for traffic violations in the same way that some believe that police use racial profiling in traffic stops where there is suspicion that the vehicle contains drugs or other contraband. However, as we note above, there is a critical difference between traffic stops involving traffic violations and stops where police suspect contraband. In the case of vehicle searching, police are likely to use driver characteristics because they cannot observe whether or not there is contraband in the vehicle. In the case of traffic violations, police can observe the transgression before making stop, rendering profiling unnecessary. Therefore, discrimination in traffic stops is an unlikely explanation for the difference in day versus night ticketing rates. 
A second explanation, which seems more plausible, is that at night police focus on more dangerous behaviors such as drunk and reckless driving, in which men may be more likely to engage. Therefore, men may be more likely to get tickets at night, while women are more likely to get tickets during the day, when police are focused on speeding, defective equipment, and other routine violations. Providing some support for this explanation is the fact that in all three locations with information on the time of the traffic stop, Bloomington, Boston, and Wichita, the proportion of stops resulting in a ticket is lower at night than it is during the day. This fact is consistent with the argument that the police are focused on more dangerous, but less easily observed criminal behaviors. When they find no evidence of these in cars that they stop, they let them go without issuing a ticket. During the day, in contrast, they are focused on basic violations that may be more easily observed. Therefore, ticketing rates are higher during the day.

We find further support for the second explanation in the proportion of traffic stops resulting in arrests for more serious criminal offenses. In Wichita, nearly 18 percent of nighttime stops resulted in either a misdemeanor or felony arrest, while less than 6 percent of daytime stops resulted in an arrest. Similarly, in Boston more than half of traffic stops resulting in citations for more serious offenses including possession of drugs, driving under the influence, and automobile theft occurred at night, despite the fact that nighttime stops make up only about 20 percent of all traffic stops in the Boston dataset. Moreover, US Department of Justice surveys $(2001,2005)$ find that men report being three times more likely than women to be arrested following traffic stops. The fact that women are less prone to engage in serious criminal behaviors may explain why they are less likely to be ticketed at night.

Finally, because we do not know the gender distribution of drivers during different times of the day, we cannot test the hypothesis that police stop men relatively more frequently during the day. Nonetheless, we do note that in all three locations for which we have data on the time of traffic stops, the proportion of stops involving female drivers is higher during the day than at night. This argues against the hypothesis that police tend to stop male drivers more frequently during the day than at night, though it may simply reflect the fact that women drive relatively less frequently at night. 


\section{CONCLUSION}

Using data from five locations in the US, we examine whether male drivers are more likely than female drivers to be ticketed when stopped by the police. Overall, we find little support for the conventional wisdom that women are less likely than men to receive a ticket at traffic stops. A pooled analysis for all five locations provides no evidence that men are more likely than women to be ticketed when stopped by the police. When we conduct separate analyses for each of the five locations, the results show that in three of them (Bloomington, Tennessee, and Wichita), women are more likely to receive a ticket at a traffic stop. This pattern of results holds for all violations and for moving violations. For non-moving violations the pattern is different, but again fails to provide evidence for the conventional wisdom that women are treated more leniently. When we look at younger women, we find some support for the conventional wisdom that younger women are treated more leniently, but the evidence is still quite weak. Finally, when we compare ticketing rates by gender for daytime and nighttime, we find some support for the conventional wisdom in that women are usually less likely to receive a ticket at night. This could indicate that police discriminate against men by stopping them more frequently. However, it may simply reflect differences in police priorities at nighttime.

While casting substantial doubt on the conventional wisdom that females are treated more leniently by police at traffic stops, our analysis raises the question of why the conventional wisdom is so pervasive in our survey samples, in spite of the empirical evidence to the contrary. The reason for this discrepancy between perceptions and empirical evidence offers an intriguing topic for future research. Our analysis also leaves open the question of why the results differ so strongly across locations. We cannot explain why women fare better than men during traffic stops in Boston but worse than men in Wichita. Nonetheless, the fact that the results differ so much across regions is itself an interesting finding. It is striking that in all five locations we found a statistically significant effect of gender on the probability of a ticket even though the sign of the effect differs across locations. One might have expected a priori that "a traffic stop is a traffic stop" whether it happens in Bloomington or Highland Park, so that all available data from the various regions should be pooled in an analysis. As we have seen, the conclusion from the pooled regression would be that traffic ticketing is gender-blind, since the gender effect is negligible in magnitude and statistically insignificant. In fact, a clear result of the paper is that gender definitely matters in as regards one's probability of being ticketed at a traffic stop, but in 
way that varies across different locations. How and why the mechanisms leading to these gender differences vary across regions presents an interesting question for future research that is likely to pay dividends beyond the narrow context of traffic stops.

Understanding the role of gender in power relationships in the complex environments of (internal or external) labor markets is a daunting task. The heavy focus in the labor economics literature has been on gender differences in labor market rewards, particularly compensation. The complex and heterogeneous nature of the behaviors being rewarded, the reward schemes themselves, the environments in which production occurs, as well as the repeated nature of interactions complicate the analysis of gender differences in labor market rewards. We see our focus on punishments rather than rewards, and on power relationships outside labor markets, as distinct advantages in analyzing gender differences in outcomes. While our analysis leaves open some important questions about the mechanisms generating gender differences in outcomes, it clearly shows that gender matters in influencing the probability of a ticket conditional on being stopped, and in a way that differs markedly by geographic location. It is a striking finding that gender matters even in such a simple, clearly defined, non-repeated, two-person interaction that rarely exceeds ten minutes in duration. Whatever mechanisms are driving these results, it seems unlikely that they would apply only to the simple case of traffic stops. We would expect them to apply in a variety of other power relationships (e.g., child rearing, student-teacher interactions, supervisor-worker interactions, the behavior of judges and juries in a courtroom, etc.). Thus, future work aimed at understanding better the mechanisms underlying the clear gender differences we have identified in the simple context of traffic stops should shed significant light on the role of gender in power relationships in the more complex settings of labor markets and beyond. 


\section{REFERENCES}

Altonji, Joseph G., and Rebecca M. Blank (1999): "Race and Gender in the Labor Market," in Handbook of Labor Economics, Volume 3C, edited by Orley Ashenfelter and David Card, Elsevier, New York.

Antonovics, Kate, and Brian G. Knight (2004): “A New Look at Racial Profiling: Evidence from the Boston Police Department." National Bureau of Economic Research Working Paper No. 10634, Cambridge, MA.

Anwar, Shamena, and Hanming Fang (2006): "An Alternative Test of Racial Prejudice in Motor Vehicle Searches: Theory and Evidence," American Economic Review, 96(1), pp. 127-151.

Arrow, Kenneth (1973): "The Theory of Discrimination," in Discrimination in Labor Markets, edited by O.A. Ashenfelter and A. Rees, Princeton University Press, Princeton, NJ, pp. 3-33.

Becker, Gary S. (1957): The Economics of Discrimination, University of Chicago Press, Chicago, IL.

Bjerk, David (2005): "Racial Profiling, Statistical Discrimination, and the Effect of a Colorblind Policy on the Crime Rate." Mimeo, McMaster University.

Blau, Francine D., and Jed DeVaro (2006): "New Evidence on Gender Differences in Promotion Rates: An Empirical Analysis of a Sample of New Hires," Industrial Relations, forthcoming.

Byrne, Donn (1971): The Attraction Paradigm, Academic Press, New York.

Carrington, William J., and Kenneth R. Troske (1998): "Sex Segregation in U.S. Manufacturing," Industrial and Labor Relations Review, 51(3), pp. 445-465.

Dee, Thomas S. (2005): “A Teacher Like Me: Does Race, Ethnicity or Gender Matter?," American Economic Review, 95(2), pp. 158-165.

Dharmapala, Dhammika, and Stephen L. Ross (2004): "Racial Bias in Motor Vehicle Searches: Additional Theory and Evidence," Contributions to Economic Analysis and Policy, 3(1), pp. 121 .

Donohue, John J., and Steven D. Levitt (2001): "The Impact of Race on Policing and Arrests," Journal of Law and Economics, 44(2), 367-394.

Eagly, Alice H. (1987): Sex Differences in Social Behavior: A Social Role Interpretation, Earlbaum, Hillsdale, NJ.

Giulano, Laura, David I. Levine, and Jonathan Leonard (2006a): "Do Race, Gender, and Age Differences Affect Manager-Employee Relations? An Analysis of Quits, Dismissals, and Promotions at a Large Retail Firm," Working paper, Center for Responsible Business, University of California, Berkeley. 
Giuliano, Laura, David I. Levine, and Jonathan Leonard (2006b): "Race, Gender, and Hiring Patterns: Evidence from a Large Service-Sector Employer.” Working Paper, University of Miami.

Grogger, Jeffrey, and Greg Ridgeway (2005): “Testing for Racial Profiling in Traffic Stops from Behind a Veil of Darkness," Journal of the American Statistical Association, forthcoming.

Hernandez-Murillo, Ruben, and John Knowles (2004): "Racial Profiling or Racist Policing?: Testing in Aggregated Data," International Economic Review, 45(3), pp. 959-989.

Knowles, John, Nicola Persico, and Petra Todd (2001): "Racial Bias in Motor Vehicle Searches: Theory and Evidence.” Journal of Political Economy, 2001, 109(11), 203-229.

Langan, Patrick A., Lawrence A. Greenfeld, Steven K. Smith, Matthew R. Durose, David J. Levin (2001). "Contacts between Police and the Public: Findings from the 1999 National Survey.” Bureau of Justice Statistics Report NCJ 184957.

Durose, Matthew R., Patrick A. Langan, Erica L. Schmitt (2005). "Contacts between Police and the Public: Findings from the 1999 National Survey." Bureau of Justice Statistics Report NCJ 207845.

Persico, Nicola, and Petra Todd (2004): "Using Hit Rate Tests to Test for Racial Bias in Law Enforcement: Vehicle Searches in Wichita," National Bureau of Economic Research Working Paper No. 10947, Cambridge, MA.

Pfeffer, Jeffrey (1983): "Organizational Demography," in Research in Organizational Behavior 5, edited by Barry M. Staw and L.L. Cummings, JAI Press, CT.

Phelps, Edmund S. (1972): "The Statistical Theory of Racism and Sexism," American Economic Review 62(4): 659-661.

Staines, G., C. Tavris, and T.E. Jayaratne. (1973): “The Queen Bee Syndrome," in The Female Experience edited by C. Tavris, CRM Books, Del Mar, CA.

Tajfel, Henri, and John C. Turner (1986): "The Social Identity Theory of Intergroup Behavior," in Psychology of Intergroup Relations (2nd ed.), edited by S. Worschel \& W.G. Austin, NelsonHall, Chicago, pp. 7-24.

Tsui, Anne S. and Charles A. O'Reilly, III (1989): "Beyond Simple Demographic Effects: The Importance of Relational Demography in Superior-Subordinate Dyads," Academy of Management Journal, 32(2), pp. 402-423.

Wesolowski Mark A. and Kevin W. Mossholder (1997): "Relational Demography in SupervisorSubordinate Dyads: Impact on Subordinate Job Satisfaction, Burnout, and Perceived Procedural Justice," Journal of Organizational Behavior, 18(4), pp. 351-362. 
Table 1: Are males or females more likely to be ticketed when stopped?

\begin{tabular}{|c|c|c|c|c|}
\hline \# Respondents & Males & Females & Equal & Sample Composition \\
\hline $\begin{array}{l}25 \text { AEM } 424 \text { students } \\
\text { at Cornell U. }\end{array}$ & 20 & & 5 & $\begin{array}{l}\text { Mostly seniors, some juniors, } \\
\text { nearly all AEM majors, } 50 \% \\
\text { male }\end{array}$ \\
\hline $\begin{array}{l}61 \text { AEM } 424 \text { students } \\
\text { at Cornell U. }\end{array}$ & 50 & 3 & 7 & $\begin{array}{l}\text { Mostly seniors, some juniors, } \\
\text { nearly all AEM majors, } 65 \% \\
\text { male }\end{array}$ \\
\hline $\begin{array}{l}54 \text { ECON/ILRLE } 443 \\
\text { students at Cornell U. }\end{array}$ & 46 & 1 & 6 & $\begin{array}{l}\text { Mostly juniors and seniors, } \\
\text { about } 2 / 3 \text { majoring in economics } \\
\text { and } 1 / 3 \text { in industrial and labor } \\
\text { relations, } 61 \% \text { male }\end{array}$ \\
\hline $\begin{array}{l}282 \text { AEM } 240 \text { students } \\
\text { at Cornell U. }\end{array}$ & 251 & 12 & 19 & $\begin{array}{l}\text { About } 1 / 3 \text { AEM majors, roughly } \\
\text { evenly distributed among } \\
\text { sophomores, juniors, and } \\
\text { seniors, with a few freshmen }\end{array}$ \\
\hline $\begin{array}{l}45 \text { students at Queen's } \\
\text { College }\end{array}$ & 36 & 2 & 7 & $\begin{array}{l}17 \text { students from an analytical } \\
\text { problem solving business class; } \\
28 \text { from a law and ethics class; } \\
\text { all are minors in business and } \\
\text { liberal arts; about } 50 \% \text { male in } \\
\text { both classes }\end{array}$ \\
\hline $\begin{array}{l}37 \text { students at } \\
\text { Northwestern U. }\end{array}$ & 28 & 1 & 8 & $\begin{array}{l}\text { First-year students in the } \\
\text { required strategy course for the } \\
\text { Kellogg MBA program; about } \\
60 \% \text { male }\end{array}$ \\
\hline $\begin{array}{l}37 \text { students at } \\
\text { Wesleyan U. }\end{array}$ & 27 & 4 & 6 & $\begin{array}{l}\text { Freshmen and sophomore } \\
\text { economics course, } 59 \% \text { male }\end{array}$ \\
\hline$T O T A L=539$ & 458 & 23 & 58 & \\
\hline Percent $=100$ & 85.0 & 4.3 & 10.7 & \\
\hline
\end{tabular}

Notes: AEM is an acronym for Applied Economics and Management and ILRLE is an acronym for Industrial and Labor Relations Labor Economics. The exact wording of the survey question is as follows: A driver is pulled over by police at a speed trap. The vehicle was traveling 12 miles over the speed limit. The officer is male and has the discretion to either issue a ticket or let the driver off with a warning. In this situation, would you say that:

a) a ticket is more likely to be issued if the driver is male?

b) a ticket is more likely to be issued if the driver is female?

c) male and female drivers are equally likely to be issued a ticket? 
Table 2: Reasons for Stop Codings by Location

\begin{tabular}{|c|c|c|c|c|c|}
\hline & Bloomington & Boston & Highland Park & Tennessee & Wichita \\
\hline $\begin{array}{l}\text { Reason } \\
\text { For } \\
\text { Stop }^{\text {a }}\end{array}$ & $\begin{array}{ll}\text { 1. } & \begin{array}{l}\text { Moving } \\
\text { violation }\end{array} \\
\text { 2. } & \begin{array}{l}\text { Equipment } \\
\text { violation }\end{array} \\
\text { 3. } & \text { Expired } \\
\text { paperwork }\end{array}$ & $\begin{array}{l}\text { 1. Moving } \\
\text { violation } \\
\text { 2. Equipment } \\
\text { violation } \\
\text { 3. Expired } \\
\text { paperwork } \\
\text { 4. Seatbelt }\end{array}$ & $\begin{array}{l}\text { 1. Moving violation } \\
\text { 2. Equipment } \\
\text { violation } \\
\text { 3. Expired } \\
\text { paperwork }\end{array}$ & $\begin{array}{l}\text { 1. Moving violation } \\
\text { 2. Equipment } \\
\text { violation }\end{array}$ & $\begin{array}{l}\text { 1. Moving violation } \\
\text { 2. Equipment } \\
\text { violation }\end{array}$ \\
\hline
\end{tabular}

${ }^{\mathrm{a}}$ Each of the datasets also includes a variety of other reasons for stops which we were unable to categorize.

However, these other reasons for stops comprise a very small fraction of the total observations in each dataset.

Table 3: Means (Standard Deviations) of Variables by Location

\begin{tabular}{|c|c|c|c|c|c|}
\hline & Bloomington & Boston & Highland Park & Tennessee & Wichita \\
\hline Ticket Issued & $\begin{array}{c}0.70 \\
(0.46)\end{array}$ & $\begin{array}{c}0.55 \\
(0.50)\end{array}$ & $\begin{array}{c}0.54 \\
(0.50)\end{array}$ & $\begin{array}{c}0.78 \\
(0.41)\end{array}$ & $\begin{array}{c}0.78 \\
(0.42)\end{array}$ \\
\hline Female Driver & $\begin{array}{c}0.40 \\
(0.49)\end{array}$ & $\begin{array}{c}0.29 \\
(0.45) \\
\end{array}$ & $\begin{array}{c}0.41 \\
(0.49) \\
\end{array}$ & $\begin{array}{c}0.34 \\
(0.47) \\
\end{array}$ & $\begin{array}{c}0.36 \\
(0.48) \\
\end{array}$ \\
\hline Mean MPH & $\begin{array}{l}47.58 \\
(10.88)\end{array}$ & $\begin{array}{l}41.83 \\
(12.36) \\
\end{array}$ & $\begin{array}{l}21.36 \\
(30.12) \\
\end{array}$ & - & - \\
\hline $\begin{array}{l}\text { Mean MPH } \\
\text { Over the Limit }\end{array}$ & $\begin{array}{l}15.06 \\
(5.51)\end{array}$ & $\begin{array}{l}14.11 \\
(5.02)\end{array}$ & $\begin{array}{l}19.63 \\
(5.35)\end{array}$ & - & - \\
\hline $\begin{array}{l}\text { Percent } \\
\text { Nighttime Stops } \\
\text { (8pm-6am) }\end{array}$ & $\begin{array}{c}0.29 \\
(0.45)\end{array}$ & $\begin{array}{c}0.18 \\
(0.39)\end{array}$ & - & - & $\begin{array}{c}0.35 \\
(0.48)\end{array}$ \\
\hline $\begin{array}{l}\text { Percent Male } \\
\text { Police Officers }\end{array}$ & 0.97 & 0.87 & 0.93 & 0.90 & 0.89 \\
\hline $\begin{array}{l}\text { Number of } \\
\text { Observations }\end{array}$ & 11,688 & 176,033 & 4,620 & 15,404 & 36,374 \\
\hline $\begin{array}{l}\text { Dates of } \\
\text { Observations }\end{array}$ & $\begin{array}{l}\text { January } 2004- \\
\text { May } 2005\end{array}$ & $\begin{array}{l}\text { April 2001- } \\
\text { January 2003 }\end{array}$ & $\begin{array}{l}\text { January } 2004- \\
\text { December } 2004\end{array}$ & $\begin{array}{l}\text { January 2001- } \\
\text { February } 2001\end{array}$ & $\begin{array}{l}\text { January } 2001- \\
\text { September } 2001\end{array}$ \\
\hline
\end{tabular}

${ }^{a}$ Police officer data are from the Uniform Crime Reporting Program Data: Police Employee (LEOKA) Data for the following years: Bloomington (2003), Boston(2002), Highland Park (2003), Tennessee (2001), and Wichita (2001). 2003 is the last year for which we were able to obtain data. 
Table 4: Male Versus Female Ticketing Rates, Pooled Estimation of All Locations with Location Fixed Effects.

\begin{tabular}{|l|l|c|}
\hline & & All Locations \\
\hline All Violations & & \\
\cline { 2 - 3 } & Female ME & -0.003 \\
& & $(0.002)$ \\
\cline { 2 - 3 } & Male Mean & 0.601 \\
\cline { 2 - 3 } & $\mathrm{N}$ & 244,119 \\
\hline
\end{tabular}

Female marginal effects (ME) indicate differences in predicted probabilities of receiving a ticket. Male means indicate the faction of men receiving a ticket. Standard errors are in parenthesis.

Table 5: Male vs. Female Ticketing Rates by Type of Violation

\begin{tabular}{|c|c|c|c|c|c|c|}
\hline & & Bloomington & Boston & Highland Park & Tennessee & Wichita \\
\hline \multirow{4}{*}{$\begin{array}{l}\text { Panel A } \\
\text { All Violations }\end{array}$} & & & & & & \\
\hline & Female ME & $\begin{array}{l}0.032 * * \\
(0.009)\end{array}$ & $\begin{array}{l}-0.017 * * \\
(0.003)\end{array}$ & $\begin{array}{l}-0.041^{* *} \\
(0.014)\end{array}$ & $\begin{array}{c}0.015^{*} \\
(0.007)\end{array}$ & $\begin{array}{l}0.038^{* *} \\
(0.004)\end{array}$ \\
\hline & Male Mean & 0.683 & 0.552 & 0.553 & 0.776 & 0.764 \\
\hline & $\mathrm{N}$ & 11,688 & 176,033 & 4,620 & 15,404 & 36,374 \\
\hline \multirow{4}{*}{$\begin{array}{l}\text { Panel B } \\
\text { Moving Violations }\end{array}$} & & & & & & \\
\hline & Female ME & $\begin{array}{l}0.047 * * \\
(0.010)\end{array}$ & $\begin{array}{l}-0.043 * * \\
(0.003)\end{array}$ & $\begin{array}{l}-0.044 * * \\
(0.015)\end{array}$ & $\begin{array}{l}0.020^{*} \\
(0.008)\end{array}$ & $\begin{array}{l}0.010^{*} \\
(0.005)\end{array}$ \\
\hline & Male Mean & 0.729 & 0.560 & 0.579 & 0.810 & 0.843 \\
\hline & $\mathrm{N}$ & 7,366 & 109,171 & 4,309 & 10,354 & 23,875 \\
\hline \multirow{4}{*}{$\begin{array}{l}\text { Panel C } \\
\text { Non-Moving } \\
\text { Violations }\end{array}$} & & & & & & \\
\hline & Female ME & $\begin{array}{l}-0.023 \\
(0.017)\end{array}$ & $\begin{array}{l}0.057 * * \\
(0.006)\end{array}$ & $\begin{array}{l}-0.015 \\
(0.045)\end{array}$ & $\begin{array}{l}-0.008 \\
(0.014)\end{array}$ & $\begin{array}{c}0.001 \\
(0.013)\end{array}$ \\
\hline & Male Mean & 0.631 & 0.543 & 0.192 & 0.721 & 0.795 \\
\hline & $\mathrm{N}$ & 3,728 & 29,774 & 306 & 4,845 & 4,804 \\
\hline \multirow{4}{*}{$\begin{array}{l}\text { Panel D } \\
\text { Speeding Violations }^{\mathrm{a}}\end{array}$} & & & & & & \\
\hline & Female ME & $\begin{array}{l}0.037 * * \\
(0.010)\end{array}$ & $\begin{array}{l}-0.054 * * \\
(0.005)\end{array}$ & $\begin{array}{c}0.001 \\
(0.001)\end{array}$ & & \\
\hline & Male Mean & 0.836 & 0.536 & 0.943 & & \\
\hline & $\mathrm{N}$ & 4,268 & 41,213 & 1,794 & & \\
\hline
\end{tabular}

+ significant at $0.10 ; *$ significant at $0.05 ; * *$ significant at 0.01 . Female marginal effects (ME) indicate differences in predicted probabilities of receiving a ticket. Male means indicate the fraction of men receiving a ticket. Standard errors are in parenthesis.

${ }^{a}$ Includes miles over and (miles over) ${ }^{2}$ as control variables. 
Table 6: Ticketing Rates Controlling for Vehicle and Driver Characteristics

\begin{tabular}{|c|c|c|c|c|c|c|}
\hline & & Bloomington & Boston & Highland Park & Tennessee & Wichita \\
\hline \multirow{4}{*}{$\begin{array}{l}\text { Panel A } \\
\text { Vehicle } \\
\text { Controls }^{\mathrm{a}}\end{array}$} & & & & & & \\
\hline & Female ME & $\begin{array}{l}0.017+ \\
(0.009)\end{array}$ & $\begin{array}{l}-0.025^{* *} \\
(0.003)\end{array}$ & & & \\
\hline & Male Mean & 0.685 & 0.559 & & & \\
\hline & $\mathrm{N}$ & 11,368 & 116,691 & & & \\
\hline \multirow{10}{*}{$\begin{array}{l}\text { Panel B } \\
\text { Driver } \\
\text { Controls }\end{array}$} & & & & & & \\
\hline & Female ME & $\begin{array}{l}0.027 * * \\
(0.009)\end{array}$ & $\begin{array}{l}-0.015^{* *} \\
(0.003)\end{array}$ & $\begin{array}{l}-0.044 * * \\
(0.015)\end{array}$ & $\begin{array}{l}0.012+ \\
(0.007)\end{array}$ & $\begin{array}{l}0.037 * * \\
(0.004)\end{array}$ \\
\hline & Male Mean & 0.683 & 0.552 & 0.553 & 0.776 & 0.764 \\
\hline & $16-24^{b}$ & $\begin{array}{l}0.043 * * \\
(0.014)\end{array}$ & $\begin{array}{l}0.057 * * \\
(0.004)\end{array}$ & & $\begin{array}{l}0.014 \\
(0.010)\end{array}$ & $\begin{array}{l}0.027 * * \\
(0.008)\end{array}$ \\
\hline & $25-34^{b}$ & $\begin{array}{l}0.094 * * \\
(0.014)\end{array}$ & $\begin{array}{l}0.036^{* *} \\
(0.004)\end{array}$ & & $\begin{array}{l}0.010 \\
(0.010)\end{array}$ & $\begin{array}{l}-0.004 \\
(0.008)\end{array}$ \\
\hline & $35-50^{b}$ & $\begin{array}{l}0.063 * * \\
(0.015)\end{array}$ & $\begin{array}{l}0.007+ \\
(0.004)\end{array}$ & & $\begin{array}{l}-0.009 \\
(0.011)\end{array}$ & $\begin{array}{l}-0.015+ \\
(0.008)\end{array}$ \\
\hline & Black & $\begin{array}{l}-0.096^{* *} \\
(0.012)\end{array}$ & $\begin{array}{l}-0.054 * * \\
(0.003)\end{array}$ & $\begin{array}{l}-0.091 * * \\
(0.030)\end{array}$ & $\begin{array}{l}-0.000 \\
(0.007)\end{array}$ & $\begin{array}{l}-0.094 * * \\
(0.006)\end{array}$ \\
\hline & Hispanic & $\begin{array}{l}-0.015 \\
(0.022)\end{array}$ & $\begin{array}{l}0.003 \\
(0.004)\end{array}$ & $\begin{array}{l}-0.019 \\
(0.027)\end{array}$ & $\begin{array}{l}-0.088^{* *} \\
(0.022)\end{array}$ & $\begin{array}{l}-0.005 \\
(0.008)\end{array}$ \\
\hline & Other & $\begin{array}{l}0.038 \\
(0.024)\end{array}$ & $\begin{array}{l}-0.007+ \\
(0.004)\end{array}$ & $\begin{array}{l}0.038 \\
(0.036)\end{array}$ & & $\begin{array}{l}0.034 * * \\
(0.010)\end{array}$ \\
\hline & $\mathrm{N}$ & 11,688 & 175,881 & 4,620 & 1,5368 & 36,315 \\
\hline
\end{tabular}

+significant at $0.10 ; *$ significant at $0.05 ; * *$ significant at 0.01 . Female marginal effects (ME) indicate differences in predicted probabilities of receiving a ticket. Male means indicate the fraction of men receiving a ticket. Standard errors are in parenthesis.

${ }^{\mathrm{a}}$ Includes dummy variables for vehicle model, year, and primary color. ${ }^{\mathrm{b}}$ In Tennessee the age categories are: 16-25; $26-35 ; 36-45$. 


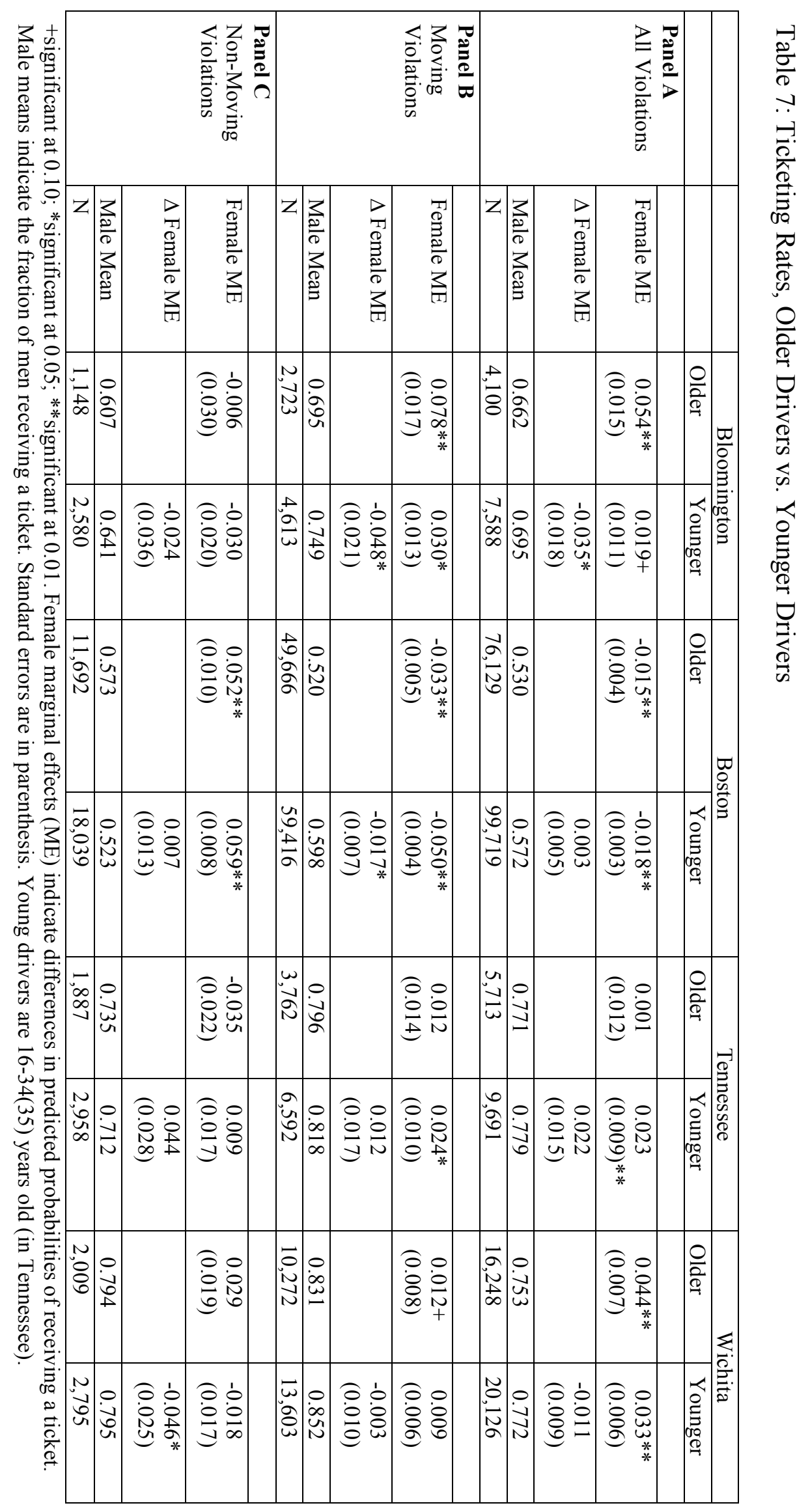




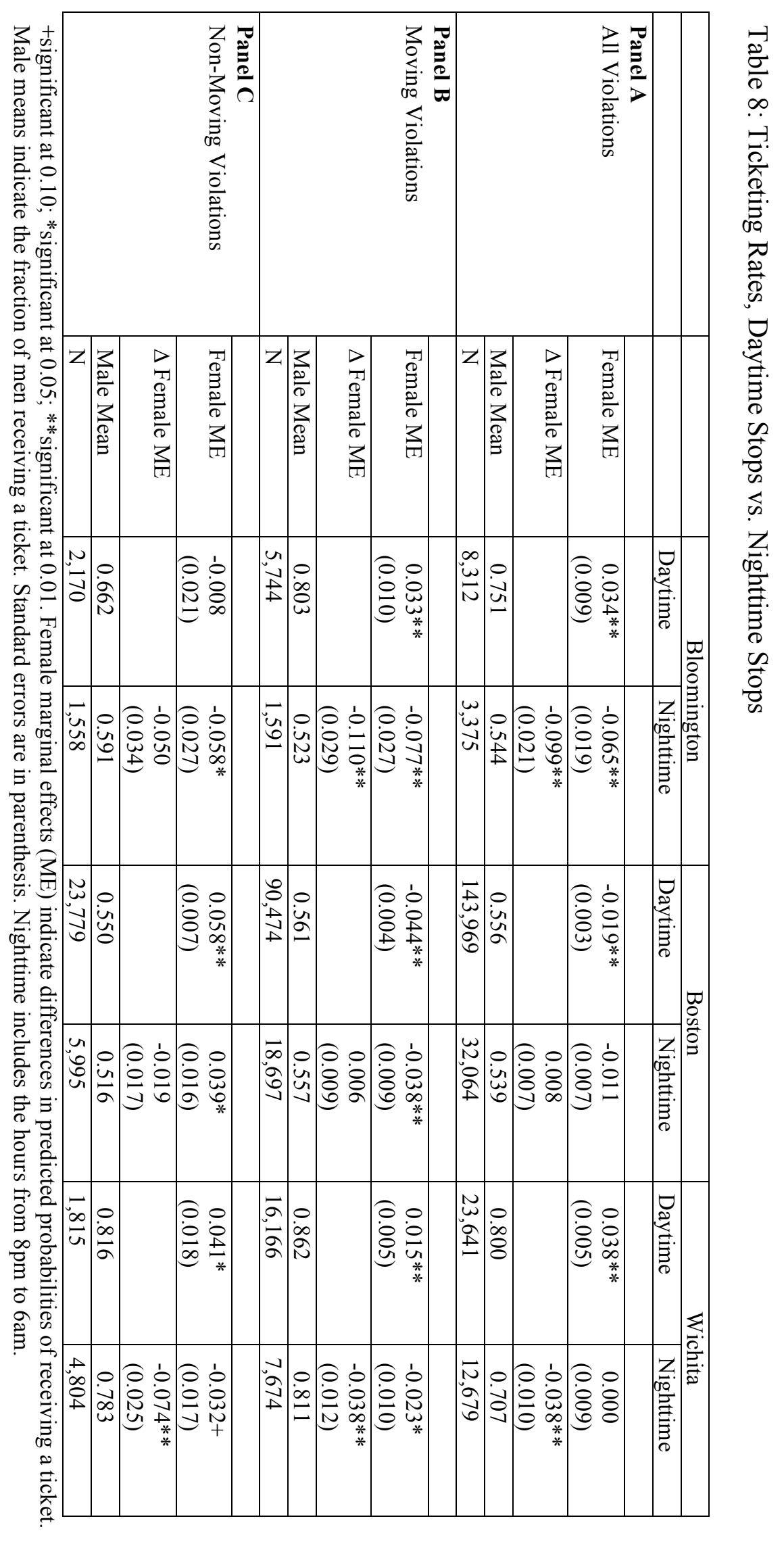

